\title{
Pengaruh Variasi Campuran Gula Pasir terhadap Kuat Tekan Mortar Semen
}

\author{
Yudira Alfazar ${ }^{1}$, Gusneli Yanti ${ }^{2}$, Shanti Wahyuni Megasari ${ }^{3}$. \\ Program Studi Teknik Sipil, Fakultas Teknik, Universitas Lancang Kuning \\ Jl. Yos Sudarso km. 8 Rumbai, Pekanbaru, Telp. (0761) 52324 \\ Email: yudira.alfazar@gmail.com, gusneli@unilak.ac.id, shanti@unilak.ac.id
}

\begin{abstract}
ABSTRAK
Mortar semen digunakan sebagai bahan pengisi dalam pekerjaan konstruksi. Namun permasalahan di lapangan mortar semen cepat mengeras akibat proses hidrasi sehingga pekerjaannya menjadi lebih sulit sehingga mempengaruhi kualitas yaitu kuat tekannya. Untuk itu digunakan bahan tambah sebagai penunda waktu ikat awal semen agar memudahkan pekerjaannya namun tidak mengurangi kualitas mortar semen. Bahan tambah yang mampu menunda waktu ikat awal semen adalah gula. sehingga dilakukan penelitian adanya pengaruh variasi campuran gula pasir terhadap kuat tekan mortar semen. Penelitian ini menggunakan gula merek Value plus, Berlian jaya, Gulaku, dan Lokal dengan penambahan 0\%, 0,05\%, 0,1\%, 0,15\% 0,2\% dari berat semen. Pembuatan benda uji sesuai dengan job mix menggunakan perbandingan campuran 1:5 (semen : pasir) dan FAS 0,5 . Berdasarkan hasil pengujian bahwa nilai kuat tekan yang tertinggi pada merek gulaku sebesar $16,35 \mathrm{MPa}$ pada campuran $0,15 \%$ nilai kuat tekan terendah pada gula merek Lokal sebesar 13,20 MPa pada campuran $0,2 \%$. Hasil analisis statistik didapatkan $F_{\text {Hitung }}$ gula Merek Value plus $=40,7$, Berlian jaya $=25,28$, Gulaku $=$ 16,37, dan Lokal $=15$. Sedangkan $F_{\text {tabel }}$ untuk $F_{0,05}=3,48$ dan $F_{0,01}=6,55$. Dari hasil penelitian diperoleh $F_{\text {hitung }}$ $>\mathrm{F}_{\text {tabel }}$ sehingga didapat kesimpulan bahwa penambahan gula pasir berpengaruh terhadap kuat tekan mortar semen.
\end{abstract}

Kata kunci : Gula, Kuat tekan, Mortar semen.

ABSTRACT

Mortar cement is used as a filler in construction works. But the problems in the field of mortar mortar quickly hardened due to the hydration process so that the work becomes more difficult that affect the quality of the compressive strength. For that purpose, the added material is used as the delay of the initial tie of cement in order to facilitate its work but does not reduce the quality of cement mortar. The added ingredients that are capable of delaying the initial bonding time are sugar. so that the influence of variation of sugar mixture to the compressive strength of cement mortar. This research uses brand sugar Value plus, Berlian jaya, Gulaku, and Lokal with the addition of 0\%, 0,05\%,0,1\%,0,15\% 0,2\% of the weight of cement. Preparation of the specimens according to the job mix using a ratio of 1:5 mixture (cement: sand) and FAS 0,5. Based on the test result that the highest value of compressive strength in the Gulaku brand is 16,35 MPa at 0,15\% mixture of the lowest compressive strength Value at Lokal brand sugar at 13,20 MPa at 0,2\% mixture. The result of statistical analysis was obtained by $F_{\text {count }}$ Sugar Brand Value plus $=40,7$, Berlian jaya $=25,28$, Gulaku $=16,37$, and Lokal $=15,00$ While $F_{\text {tabel }}$ for $F_{0,05}=3,48$ and $F_{0,01}=6,55$ From result of research obtained $F_{\text {count }}>F_{\text {tabel }}$ so that got conclusion that addition of sugar sand have an effect on to compressive strength of mortar cement

Keywords: Sugar, Compresive strength, Cement mortar.

\section{PENDAHULUAN}

Mortar adalah campuran dari semen, air, dan agregat halus yang digunakan dalam pekerjaan sipil sebagai bahan perekat dan pengisi dalam pekerjaan konstruksi. Penggunaan mortar sangat luas dalam pekerjaan sipil seperti digunakan untuk pasangan bata, pasangan batu kali, plesteran, pembuatan batako, conblock dan lain lain. Dengan banyaknya kegunaan mortar tersebut, maka campuran mortar harus direncanakan dengan baik sehingga mampu menahan beban yang bekerja pada mortar itu sendiri dengan mengetahui sifat dan karakteristik pada mortar untuk menjaga kualitasnya.

Salah satu faktor yang dapat mempengaruhi kualitas pada mortar semen yaitu proses hidrasi. Hidrasi pada mortar semen adalah proses antara

Yudira, Pengaruh Variasi Campuran Gula Pasir terhadap Kuat Tekan Mortar Semen 
semen dan agregat halus mulai mengeras menjadi kaku, tidak jarang proses hidrasi yang cepat akibat suhu yang tinggi menyebabkan mortar semen menjadi cepat mengeras sehingga pekerjaan pengadukan dan pemasangan pun menjadi sulit, untuk itu diperlukan bahan tambah yang berfungsi untuk memperlambat reaksi pengikatan pada semen dan memudahkan dalam pekerjaan pencampuran tanpa mengurangi kuat tekan mortar yang sudah ditentukan.

Seiring dengan perkembangan zaman, kini telah banyak bermacam macam bahan tambah dari kimia maupun alami untuk meningkatkan kinerja dari suatu campuran. Bahan tambah yang digunakan juga mempertimbangkan material yang mudah didapat, harga yang murah dan juga ramah lingkungan. Salah satu bahan tambah yang bisa digunakan dalam adukan material berbahan semen adalah gula pasir, gula bisa sebagai bahan tambah alami yang berfungsi untuk memperlambat waktu pengikatan semen untuk adukan yang membutuhkan perlambatan pengerasan, Guna untuk mempermudah dalam pekerjaan.

Dalam Penelitian sebelumnya oleh Febringsih S (2015), meneliti tentang analisis perbandingan waktu awal ikat semen dengan variasi penambahan gula. Hasil penelitian didapatkan bahwa campuran semen dengan gula yang mengandung glukosa tinggi mengalami kenaikan waktu ikat awal pada persentase $0,15 \%$ dan turun kembali setelah melewati kadar $0,15 \%$. Berdasarkan pada penelitian sebelumnya itu maka ingin dilakukan penelitian lanjutan untuk mengetahui nilai kuat tekan pada mortar semen akibat variasi penambahan gula sebagai bahan tambah dalam memperlambat waktu ikat awal semen.

\section{METODE PENELITIAN}

\section{Lokasi Penelitian}

Penelitian dilakukan dilaboratorium beton PT. Riau Mas Bersaudara

\section{Bahan dan Alat}

Bahan-bahan yang digunakan dalam penelitian ini adalah sebagai berikut :

1. Semen yang digunakan dalam penelitian ini adalah Ordinary Portland Cement type I yang diproduksi oleh PT. Semen Padang.

2. Air yang digunakan untuk penelitian ini adalah air yang berasal dari sumur dilingkungan laboratorium beton PT. Riau Mas Bersaudara.

3. Pasir yang digunakan yaitu pasir yang berasal dari daerah Batu bersurat kabupaten Kampar

4. Gula pasir yang digunakan dalam penelitian ini adalah :

a. Gula Berlian Jaya yang diproduksi oleh CV. Rimbun Padi Berjaya - Padang.

b. Gulaku, yang diproduksi oleh PT. Sweet Indolampung. c. Value Plus, yang diproduksi oleh PT. Mawar Jaya - Jakarta.

d. Gula putih lokal yang diproduksi oleh PT. Surya Utama Sentosa - Jakarta.

Alat-alat yang digunakan dalam penelitian ini adalah :

1. Timbangan digital kapasitas 2000 gram dengan ketelitian 0.1 .

2. Saringan dan mesin pengetar saringan

3. Oven

4. Cawan.

5. Labu kaca kapasitas $1000 \mathrm{ml}$

6. Gelas ukur $100 \mathrm{ml}$

7. Sendok perata

8. Gelas ukur kapasitas $5 \mathrm{ml}$ untuk mengetahui kandungan organik dan lumpur agregat halus

9. Mixer dan mangkok pengaduk mortar

10. Sendok pengaduk

11. Alat cetakan mortar $5 \times 5 \times 5 \mathrm{~cm}^{2}$

12. Alat tekan untuk menguji kuat tekan pada mortar.

13. Bak rendaman untuk perawatan mortar.

\section{Prosedur Penelitian}

Prosedur penelitian ini meliputi persiapan benda uji yaitu data semen, agregat halus, air, dan pencampuran bahan yaitu gula pasir, pencetakan benda uji dan kuat tekan mortar semen.

1. Semen

Pada penelitian ini semen yang digunakan adalah semen Portland type I produksi PT. Semen Padang. Pada penelitian ini semen yang digunakan tidak dilakukan pengujian karena semen-semen yang digunakan memenuhi standart ASTM.

2. Agregat halus

Agregat halus yang digunakan dalam penelitian ini adalah pasir. Adapun langkah pengujian ini dilakukan sebagai berikut :

a. Pemeriksaan berat volume

Tujuan pemeriksaan menentukan berat isi agregat halus atau campuran yang didefinisikan sebagai perbandingan antara berat material kering dengan volumenya.

b. Pemeriksaan analisa saringan agregat halus Tujuan pemeriksaan metode ini dimaksudkan sebagai acuan dalam pemeriksaan untuk menentukan pembagian butir (gradasi) agregat halus menggunakan saringan, dengan tujuan memperoleh distribusi besaran atau jumlah persentase butiran baik agregat halus.

c. Pemeriksaan bahan lolos saringan no. 200 agregat halus

Tujuan pemeriksaan menentukan jumlah bahan dalam agregat halus yang lolos saringan no. 200 dengan cara pencucian.

d. Pemeriksaan kadar lumpur agregat halus Tujuan pemeriksaan untuk menentukan persentase kadar lumpur dalam agregat halus.

e. Pemeriksaan kadar air agregat halus 
Tujuan pemeriksaan untuk menentukan angka persentase kadar air agregat halus dengan cara pengeringan agregat halus dalam oven. Kadar air agregat adalah perbandingan antara berat air yang terkandung dalam agregat dengan berat agregat dalam keadaan kering. Nilai kadar air ini digunakan untuk koreksi takaran air dalam adukan beton yang disesuaikan dengan kondisi agregat di lapangan.

f. Pemeriksaan analisa bulk specific gravity dan penyerapan agregat halus

Tujuannya Pemeriksaan tujuannya untuk menentukan berat jenis (bulk specific gravity) dan penyerapan agregar halus.

3. Air

Fungsi dari air disini antara lain adalah sebagai bahan pencampur dan pengaduk antara semen dan agregat. Pada umumnya air yang dapat diminum memenuhi persyaratan sebagai air pencampur beton, air ini harus bebas dari padatan tersuspensi ataupun padatan terlarut yang terlalu banyak dan bebas dari material organik.

4. Bahan aditif

Gula pasir, adalah bahan campuran yang berfungsi sebagai penunda waktu ikat awal semen.

\section{Rancangan Benda Uji}

Pada penelitian ini Benda uji berupa mortar kubus dengan ukuran 5 x 5 x $5 \mathrm{~cm}$. dengan menggunakan Penambahan gula sebesar, $0 \%, 0,05 \%$, $0,1 \%, 0,15 \%, 2 \%$ terhadap berat semen. FAS (faktor air semen $)=0,5$. Dengan menggunakan perbandingan campuran $1: 5$ (semen : pasir).

Tabel 1. Rancangan benda uji.

\begin{tabular}{|c|c|c|c|c|c|c|}
\hline \multirow{2}{*}{ No } & \multirow{2}{*}{ Jenis Gula } & \multicolumn{5}{|c|}{ Persentase campuran gula } \\
\hline & & 0 & 0,05 & 0,1 & 0,15 & 0,2 \\
\hline 1 & Value Plus & \multirow{4}{*}{3} & 3 & 3 & 3 & 3 \\
\hline 2 & $\begin{array}{c}\text { Berlian } \\
\text { Jaya }\end{array}$ & & 3 & 3 & 3 & 3 \\
\hline 3 & Gula Lokal & & 3 & 3 & 3 & 3 \\
\hline 4 & Gulaku & & 3 & 3 & 3 & 3 \\
\hline \multicolumn{2}{|c|}{ Jumlah Gula } & 3 & 12 & 12 & 12 & 12 \\
\hline & Total & \multicolumn{5}{|c|}{51} \\
\hline
\end{tabular}

(sumber : Rancangan penelitian,2018)

\section{Rancangan Perlakuan}

Bagian dari volume mortar terdiri dari agregat halus dan sebagian lagi terdapat semen dan pori pori. Didalam penelitian ini pemilihan agregat halus berasal dari daerah Kampar, bahan dasar mortar yang digunakan dalam penelitian ini adalah semen, agregat halus, dan variasi campuran gula pasir. rancangan perlakuan dapat dilihat pada tabel 2 .

\section{Metode Analisis Data}

Analisis Varians (Anova) adalah suatu teknik statistik yang memungkinkan kita untuk mengetahui apakah dua atau lebih mean populasi akan bernilai sama dengan menggunakan data dari sampel masing masing populasi. Analisis Varians akan menjadi teknik statistik yang valid untuk diterapkan dengan menggunakan asumsi - asumsi sebagai berikut :

1. Populasi yang dikaji memiliki distribusi normal

2. Pengambilan sampel dilakukan secara acak dan setiap sampel independen tidak

terikat sampel lain.

3. Populasi populasi dimana nilai sampel - sampel diperoleh memiliki nilai varians populasi sama

Untuk rancangan perlakuan dapat dilihat pada tabel 2:

Tabel 2. Rancangan Perlakuan

\begin{tabular}{|c|c|c|c|c|}
\hline \multirow{2}{*}{ No } & \multirow{2}{*}{$\begin{array}{c}\text { Persentase } \\
\text { variasi } \\
\end{array}$} & \multicolumn{3}{|c|}{ Kuat Tekan Benda Uji (MPa) } \\
\cline { 3 - 5 } & campuran gula & $\begin{array}{c}\text { Sampel } \\
1\end{array}$ & $\begin{array}{c}\text { Sampel } \\
2\end{array}$ & $\begin{array}{c}\text { Sampel } \\
3\end{array}$ \\
\hline 1 & $0 \%$ & Y1 & Y1 & Y1 \\
\hline 2 & $0,05 \%$ & Y2 & Y2 & Y2 \\
\hline 3 & $0,10 \%$ & Y3 & Y3 & Y3 \\
\hline 4 & $0,15 \%$ & Y4 & Y4 & Y4 \\
\hline 5 & $0,20 \%$ & Y5 & Y5 & Y5 \\
\hline
\end{tabular}

(Sumber : Rancangan penelitian, 2018) tabel 3:

Untuk distribusi perlakuan dapat dilihat pada

Tabel 3. Distribusi perlakuan

\begin{tabular}{|c|c|c|c|c|c|}
\hline \multirow{2}{*}{ No } & \multirow{2}{*}{$\begin{array}{c}\text { Variasi } \\
\text { Campuran } \\
\text { Gula Pasir } \\
(\%)\end{array}$} & \multicolumn{3}{|c|}{ Kuat Tekan Benda Uji (MPa) } & \multirow{2}{*}{ Total } \\
\hline & & $\begin{array}{c}\text { Sampel } \\
1\end{array}$ & $\begin{array}{c}\text { Sampel } \\
2\end{array}$ & $\begin{array}{c}\text { Sampel } \\
3\end{array}$ & \\
\hline 1 & $0 \%$ & Y1 & Y1 & Y1 & \\
\hline 2 & $0,05 \%$ & Y2 & Y2 & Y2 & \\
\hline 3 & $0,10 \%$ & Y3 & Y3 & $\mathrm{Y} 3$ & \\
\hline 4 & $0,15 \%$ & Y4 & Y4 & Y4 & $\sum_{j-1} Y_{i j}$ \\
\hline 5 & $0,20 \%$ & Y5 & Y5 & Y5 & $\sum_{i-1} Y_{i j}$ \\
\hline
\end{tabular}

(Sumber : Rancangan penelitian,2018)

Dengan titik kritis sebaran $F$ dengan derajat bebas $\{(p-1) . P(n-1)\}$ dan pada taraf nyata $\alpha$ yang dipilih (untuk $n$ yang tidak sama), derajat bebas sebaran $F$ adalah $\left\{(p-1), \sum i(n-1)\right\}$.

FHitung $=\frac{\text { KTperlakuan }}{\text { KTpercobaan }}$

Dimana: KT perlakuan = Kuadrat tengah perlakuan KT percobaan $=$ Kuadrat tengah percobaan 


\section{Analisis Data Hasil Uji}

Untuk Mengetahui analisis data hasil uji $\mathrm{F}$ bisa dilihat pada tabel 3

Tabel 4. Analisis data hasil uji

\begin{tabular}{|c|c|c|c|c|}
\hline SK & $\mathrm{Db}$ & JK & KT & Fhitung \\
\hline $\begin{array}{c}\text { Perlakuan } \\
\text { Galat } \\
\text { Percobaan }\end{array}$ & $\begin{array}{l}(p-1) \\
(p n-1)\end{array}$ & $\begin{array}{l}n \sum^{P} i(Y- \\
Y)^{2} \\
=\mathrm{JKp} \\
n \sum^{P} i \sum^{n} i \\
(Y i 1-Y i . .)^{2} \\
=\mathrm{JKG}\end{array}$ & $\begin{array}{l}\text { KTP } \\
\text { KTG }\end{array}$ & $\mathrm{KT} p / \mathrm{KT} G$ \\
\hline Total & $(p n-1)$ & $\begin{array}{c}n \sum^{P} i \sum^{n} i \\
(Y i 1-Y i . .)^{2} \\
=\mathrm{JKT}\end{array}$ & - & - \\
\hline
\end{tabular}

(Sumber : Penelitian, 2018)

Keterangan :

SK = Sumber Keragaman

$\mathrm{Db}=$ Derajat bebas.

JK = Jumlah kuadrat.

JKp = Jumlah kuadrat perlakuan ,

$\mathrm{JKP}=\sum_{j-1}^{P}\left(\sum_{j-1}^{P} Y i J\right)^{2} / \mathrm{n}-\mathrm{FK}$

JKG = Jumlah kuadrat Galat, JKTotal-JK Perlakuan

JKT = Jumlah kuadrat Total,

$\mathrm{FK} \quad=\sum_{j-1}^{P} \sum_{j-1}^{P} Y^{2} y-\mathrm{FK}$

FK $\quad$ Faktor koreksi,

$\mathrm{FK} \quad=\left(\sum_{j-1}^{P} \sum_{j-1}^{P} Y i j\right)^{2} y / p n$

KT = Kuadrat tengah perlakuan,

$\mathrm{KT} p=$ Kuadrat tengah perlakuan,

$\mathrm{KT} p \quad=\mathrm{JKp} /(p(n-1)$

$\mathrm{KT} G=$ Kuadrat tengah $\mathrm{G}$ Perc,

$\mathrm{KT} G=\mathrm{JKp} /(p(n-1)$ untuk $n$ sama

$\mathrm{KT} G=\mathrm{JKG} /\left(\sum i(\right.$ ni-1) $n$ tidak sama

Mendistribusikan $F$ pada level signifikan

Fkritis $\alpha=0,05$ atau 0,01 . Jika $F_{\text {hitungt }}>F_{\text {tabel }}$ maka terdapat perlakuan yang sangat nyata. Dengan catatan jika $\alpha=0,05$ disebut berbeda atau berpengaruh nyata, dan jika $\alpha=0,01$ disebut berbeda atau berpengaruh sangat nyata.

\section{Langkah - Langkah Penelitian} berikut :

Langkah - langkah penelitian ini yaitu sebagai

1. Persiapan awal

Kegiatan ini meliputi pengurusan izin pemakaian laboratorium beserta alat yang dipergunakan dalam peneitian, kemudian mempersiapkan material.

2. Pengujian material
Pada tahap ini dilakukan pengujian terhadap bahan penyusun mortar yang meliputi semen dan pasir sebagai agregat halus. Dari pengujian bahan material ini dapat diketahui apakah bahan yang akan digunakan memenuhi syarat atau tidak. Untuk pasir pengujian yang dilakukan :

a. Kadar lumpur bertujuan untuk mengetahui kadar lumpur dalam pasir.

b. Kadar organik bertujuan untuk mengetahui jumlah kandungan zat organic dalam pasir.

c. Gradasi bertujuan untuk mengetahui susunan diameter butiran pasir dan persentase modulus kehalusan butir untuk menunjukkan tinggi rendahnya tingkat kehalusan butir dalam suatu agregat.

d. Specific gravity bertujuan untuk mengetahui berat jenis pasir serta daya serap pasir terhadap air.

3. Pembuatan benda uji

a. Kegiatan ini berupa penimbangan bahan bahan mortar sesuai dengan jobmix yang telah ditetapkan.

b. Mencampurkan semen dan pasir kedalam mesin pengaduk selama 30 detik, dengan kecepatan putaran mesin pengaduk adalah 140 \pm 5 putaran per menit

c. Mencampurkan gula pasir yang telah ditimbang sesuai persentase campuran yang sudah disiapkan kedalam adukan.

d. Pengadukan dihentikan, lalu motornya dibersihkan dari semen yang menempel di bibir dan bagian atas mangkok pengaduk selama 15 detik

e. Ulang kembali pengadukan selama 60 dengan kecepatan pengadukan $285 \pm 10$ putaran per menit.

f. Memasukkan adukan ke dalam cetakan kubus ukuran 5 x 5 x $5 \mathrm{~cm}$ lalu permukaannya diratakan dan diberi kode.

g. Perlu diperhatikan bahwa tebal masing masing lapisan diusahakan sama dan kekuatan pemadatan harus sama agar tingkat kepadatan sampel lebih konsisten.

h. Pekerjaan pencetakan benda uji harus sudah dimulai dalam waktu paling lama 2 1/2 menit setelah pengadukan semula

i. Permukaan kubus diratakan dengan sendok perata.

j. Bekisting atau cetakan dapat dibuka setelah 24 jam.

k. Setelah didiamkan dalam suhu lembab Selama 24 jam, sampel direndam dalam air hingga sekitar 28 hari menjelang pengujian tekan.

4. Tahap pengujian

Pada tahap ini di lakukan pengujian kuat tekan terhadap benda uji yang telah berumur 28 hari. Prosedur pengujian dilakukan sebagai berikut :

a. Mengukur panjang, lebar, tinggi benda uji 
b. Meletakkan benda uji pada ruang penekan universal testing machine

c. Memutar jarum penunjuk tepat pada titik nol, kemudian menghidupkan mesin tekan

d. Mengamati setiap perubahan/ penambahan kuat tekan pada jarum pengukurnya. Bila jarum sudah tidak bergerak lagi maka mesin dimatikan, dengan kata lain mortarnya sudah hancur.

e. Membaca dan mencatat angka pada jarum ukur yang merupakan besarnya beban tekan mortar.

5. Hasil penelitian

Kuat tekan mortar didapatkan berdasarkan pada hasil pengujian alat pembebanan.

6. Analisa dan pembahasan

Analisa didapatkan dengan menghitung besarnya kuat tekan benda uji dengan rumus 2 .

$\tau_{\mathrm{m}}=\frac{\mathrm{P}_{\mathrm{maks}}}{\mathrm{A}}$

Dengan:

$\tau_{\text {maks }}=$ Kuat tekan mortar yang didapat dari benda uji $(\mathrm{MPa})$

$\mathrm{P}_{\text {maks }}=$ Beban tekan maksimum $(\mathrm{N})$

$\mathrm{A} \quad=$ Luas permukaan benda uji $\left(\mathrm{mm}^{2}\right)$

7. Kesimpulan dan saran

\section{Bagan Alir Penelitian}

Bagan alir untuk penelitian kuat tekan bata ringan terhadap pemisahan serat pelepah kelapa sawit dengan metode kimia ini dapat dilihat pada gambar 1 .

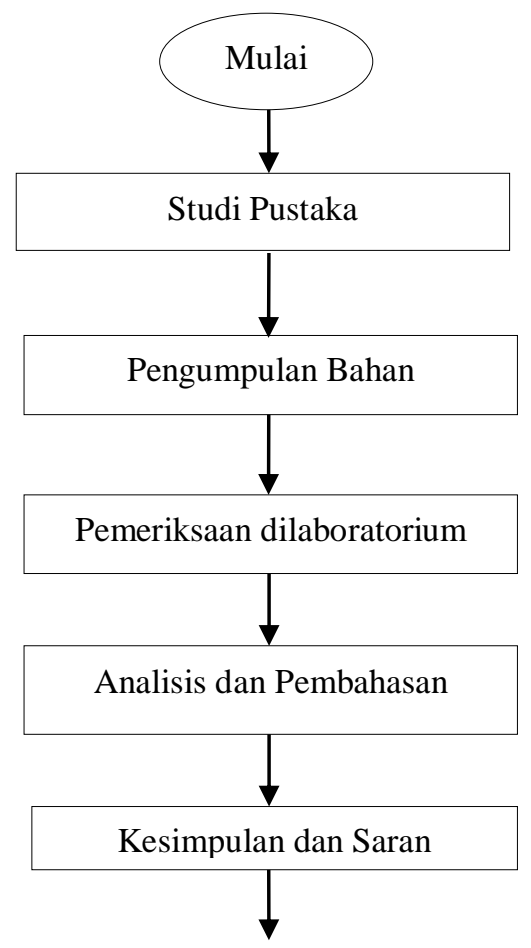

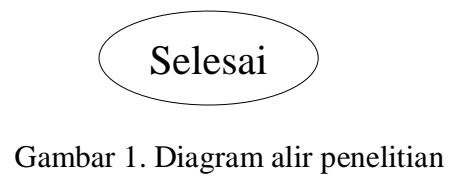

\section{HASIL DAN PEMBAHASAN}

\section{Pemeriksaan Material}

Material yang digunakan dalam penelitian ini terdiri dari agregat halus, agregat halus yang berasal dari Batu bersurat Kampar-Riau.

Tabel 5. Pengujian analisa saringan agregat halus Batu bersurat kampar

\begin{tabular}{|c|c|c|c|c|}
\hline \multirow{2}{*}{$\begin{array}{c}\text { Lubang } \\
\text { Ayakan }\end{array}$} & \multicolumn{2}{|c|}{ Tertahan } & \multicolumn{2}{c|}{ Persentase Komulatif } \\
\cline { 2 - 5 } & Berat (gr) & Jumlah (gr) & Tertinggal & Lolos \\
\hline 10 & 0,00 & 0,00 & 0,00 & 100,00 \\
\hline 5 & 2,40 & 2,40 & 0,24 & 100,00 \\
\hline 2,36 & 134,10 & 136,50 & 13,65 & 86,35 \\
\hline 1,18 & 184,80 & 321,30 & 32,13 & 67,87 \\
\hline 0,6 & 170,40 & 491,70 & 49,17 & 50,83 \\
\hline 0,3 & 306,10 & 797,80 & 79,78 & 20,22 \\
\hline 0,15 & 109,40 & 907,20 & 90,72 & 9,28 \\
\hline PAN & 92,80 & 1000,00 & 100,00 & 0,00 \\
\hline Total & 1000,00 & \multicolumn{3}{|c}{} \\
\hline yyyyy & & & & \\
\hline
\end{tabular}

(Sumber : Penelitian beton RMB,2018)

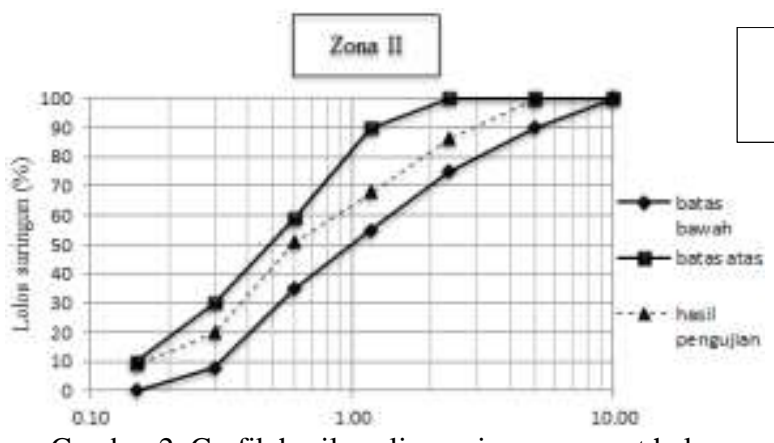

Gambar 2. Grafik hasil analisa saringan agregat halus

Maka berdasarkan grafik gradasi butiran agregat halus dapat diketahui bahwa agregat halus yang digunakan dalam penelitian ini termasuk dalam daerah atau zona II yaitu memiliki butiran agak kasar. Pemeriksaan kadar bahan organik yang terkandung didalam agregat halus didapatkan perbandingan warna cairan pada botol yang diuji lebih terang dibandingkan dengan warna cairan pada botol pembanding No.2, sehingga agregat halus dapat 
digunakan langsung dalam adukan mortar.. Dari hasil pemeriksaan berat jenis dan penyerapan agregat halus didapat nilai $\mathrm{BJ}$ kering $=2,595$ (hasil pengujian memenuhi persyaratan SNI yaitu berat jenis minimal 2,5), BJ SSD = 2,607 (hasil pengujian memenuhi persyaratan SNI yaitu berat jenis minimal 2,5), BJ semu $=2,627$ (hasil pengujian memenuhi persyaratan SNI yaitu berat jenis minimal 2,5), nilai penyerapan $0,47 \%$ (hasil pengujian memenuhi persyaratan SNI yaitu penyerapan maksimal $5 \%$ ).

\section{Campuran Mortar Semen}

Dari hasil pengujian terhadap karakteristik agregat halus dari Batu bersurat Kampar direncanakan campuran mortar dengan data-data sebagai berikut:
1. Semen yang digunakan $=$ Semen portland tipe I semen padang

2. Ukuran alat cetak benda uji $\quad=5 \mathrm{~cm} \times 5 \mathrm{~cm} \times 5$ $\mathrm{cm}$

3. Agregat halus alami zona II (agak kasar)

Adapun Job mix yang dibuat dalam penelitian ini adalah dengan perbandingan campuran $1: 5$ (semen : pasir), dengan nilai FAS (faktor air semen) 0,5 . Jumlah bahan uji material sesuai dengan Job mix yang digunakan dapat dilihat pada tabel 6 .

Tabel 6. Persentase penambahan serat pelepah kelapa sawit

\begin{tabular}{|c|c|}
\hline Normal & $\begin{array}{c}\text { Berat } \\
(\mathrm{Gr})\end{array}$ \\
\hline Semen & 202,18 \\
\hline Air & 99,71 \\
\hline Agregat Halus & 997,07 \\
\hline
\end{tabular}

(Sumber : Laboratorium PT. RMB, 2018)

Persentase penambahan variasi campuran gula pasir berdasarkan berat semen dalam 3 sampel kubus dapat dilihat pada tabel 7 .

Tabel 7. Variasi Campuran Gula pasir

\begin{tabular}{|c|c|}
\hline $\begin{array}{c}\text { Campuran Gula } \\
(\%)\end{array}$ & $\begin{array}{c}\text { Berat } \\
(\mathrm{Gr})\end{array}$ \\
\hline 0 & 0 \\
\hline 0,05 & 0,101 \\
\hline 0,1 & 0,202 \\
\hline 0,15 & 0,303 \\
\hline 0,2 & 0,404 \\
\hline
\end{tabular}

(Sumber : Laboratorium PT. RMB, 2018)

\section{Hasil Pengujian Kuat Tekan Mortar Semen}

Nilai kuat tekan mortar semen yang didapat dari dengan benda uji kubus $5 \mathrm{~cm}$ x $5 \mathrm{~cm}$ x $5 \mathrm{~cm}$ dengan umur bata ringan 28 hari. Dengan variasi persentase campuran gula pasir. Pada alat penekan beton CTM (Compression Test Machine) satuan yang dipakai adalah Kilo Newton (KN). Setelah dilakukan pengujian kuat tekan mortar semen dilaboratorium, maka hasil nilai kuat tekan rata rata benda uji dapat dilihat pada tabel 8
Tabel 8. Rata- rata kuat tekan mortar dengan variasi campuran gula pasir

\begin{tabular}{|c|c|c|c|c|c|}
\hline \multirow{2}{*}{ No } & \multirow{2}{*}{$\begin{array}{c}\text { Persentase } \\
\text { variasi } \\
\text { campuran } \\
\text { gula pasir }(\%)\end{array}$} & \multicolumn{4}{|c|}{ Kuat Tekan Benda Uji (MPa) } \\
\hline & & $\begin{array}{c}\text { Value } \\
\text { plus }\end{array}$ & $\begin{array}{c}\text { Berlian } \\
\text { jaya }\end{array}$ & Gulaku & $\begin{array}{l}\text { Gula } \\
\text { local }\end{array}$ \\
\hline 1 & $0 \%$ & 14,66 & 14,66 & 14,66 & 14,66 \\
\hline 2 & $0,05 \%$ & 15,40 & 15,17 & 15,28 & 15,28 \\
\hline 3 & $0,10 \%$ & 16,07 & 15,23 & 15,34 & 15,45 \\
\hline 4 & $0,15 \%$ & 16,24 & 15,57 & 16,35 & 16,24 \\
\hline 5 & $0,20 \%$ & 13,42 & 13,31 & 13,53 & 13,20 \\
\hline
\end{tabular}

(Sumber : Hasil Penelitian, 2018)

Dari tabel 6 diatas menunjukkan nilai kuat tekan rata-rata mortar semen dengan variasi campuran gula pasir pada umur 28 hari didapatkan nilai kuat tekan yang terus meningkat seiring dengan penambahan campuran gula pasir yaitu dengan penambahan $0,15 \%$ yaitu sebesar 16,35 MPa pada campuran gula merek gulaku, namun kuat tekan kembali turun dengan penambahan gula sebesar $0,2 \%$ sebesar $13,20 \mathrm{MPa}$ nilai kuat tekan terendah pada gula merek gula local hasil kuat tekan pada tabel 4 dapat dilihat pada gambar 3.

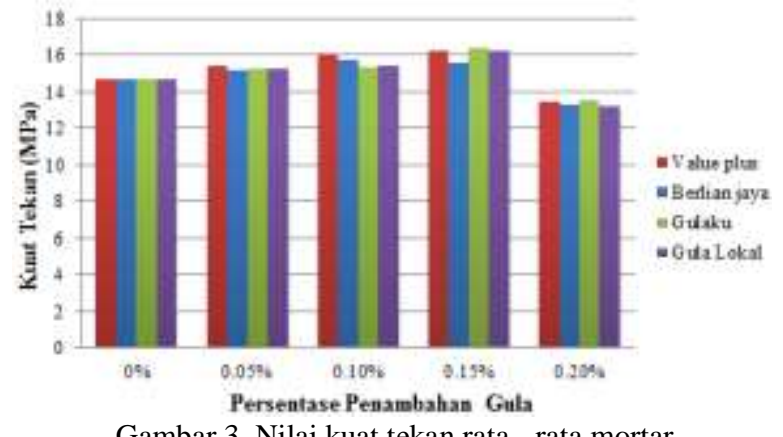

Gambar 3. Nilai kuat tekan rata - rata mortar

\section{Analisis Statistik}

Analisis statistik yang digunakan untuk menjawab identifikasi masalah pada penelitian ini, yaitu dengan langkah - langkah pengerjaan statistik sebagai berikut:

a. Menentukan notasi matematika (rancangan perlakuan) Untuk menyimpulkan pegaruh kuat tekan mortar terhadap variasi campuran gula pasir, pada setiap merek gula dilakukan dianalisis terlebih dahulu dari hasil uji kuat tekan nya.

Tabel 9. Analisis statistik pada merek gula Value Plus

\begin{tabular}{|c|c|c|c|c|c|}
\hline \multirow{2}{*}{ No } & $\begin{array}{c}\text { Variasi } \\
\text { campura } \\
\text { n gula } \\
\text { pasir (\%) }\end{array}$ & \multicolumn{2}{|c|}{ Kuat Tekan Benda Uji (MPa) } & \multirow{2}{*}{ Total } \\
\cline { 3 - 5 } 11 & $\begin{array}{c}\text { Sampe } \\
12\end{array}$ & $\begin{array}{c}\text { Sampe } \\
3\end{array}$ & Sampel & \\
\hline \multirow{2}{*}{1} & $0 \%$ & 15,23 & 14,21 & 14,55 & $\sum_{j-1}^{5} Y_{2 j}=43,99$ \\
\hline 2 & $0,05 \%$ & 14,89 & 15,73 & 15,57 & $\sum_{\mathrm{j}-1}^{5} \mathrm{Y}_{2 \mathrm{j}}=46,19$ \\
\hline
\end{tabular}




\begin{tabular}{|c|c|c|c|c|c|}
\hline 3 & $0,10 \%$ & 15,90 & 1524 & 16,07 & $\sum_{j-1} Y_{3 j}=48,22$ \\
\hline 4 & $0,15 \%$ & 16,41 & 15,90 & 16,41 & $\sum_{j-1}^{5} Y_{4 j}=48,73$ \\
\hline 5 & $0,20 \%$ & 13,57 & 12,86 & 13.87 & $\sum_{j-1}^{5} Y_{5 j}=40,27$ \\
\hline & & \multicolumn{3}{|c|}{ Total } & $\begin{array}{l}\sum_{i=1}^{4} \sum_{j=1}^{5} Y i_{j} \\
=227,39\end{array}$ \\
\hline
\end{tabular}

(Sumber : Hasil Penelitian, 2018)

1) Menentukan derajat bebas

$$
\begin{aligned}
& \mathrm{Db}_{\text {Perlakuan }}=(\mathrm{p}-1) \\
& =(5-1)=4 \\
& \mathrm{Db} \text { Percobaan }=\mathrm{p}(\mathrm{n}-1) \\
& =5(3-1)=10
\end{aligned}
$$

2) Menghitung faktor koreksi

$$
\begin{aligned}
& \text { FK }\left(\sum_{i=1}^{p}=\sum_{j=1}^{n} Y_{i j} / p . n\right. \\
& =(227,39)^{2} /(5 \times 3) \\
& =3.447,08
\end{aligned}
$$

3) Menghitung jumlah-jumlah kuadrat yang diperlukan

Jk total

$$
\begin{aligned}
& =\left(\mathrm{Y} 1 j^{2}+\mathrm{Y} 2 \mathrm{j}^{2}+\mathrm{Y} 3 \mathrm{j}^{2}\right)-\mathrm{FK} \\
& \left\{\begin{array}{l}
\mathrm{Y} 1_{1}{ }^{2}+\mathrm{Y} 1_{2}{ }^{2}+\mathrm{Y} 1_{3}^{2}+\mathrm{Y} 2_{1}{ }^{2}+\mathrm{Y} 2_{2}{ }^{2}+\mathrm{Y} 2_{3}{ }^{2}+ \\
\mathrm{Y} 3_{1}{ }^{2}+\mathrm{Y} 3_{2}^{2}+\mathrm{Y} 3_{3}^{2}+\mathrm{Y} 4_{1}^{2}+\mathrm{Y} 4_{2}^{2}+\mathrm{Y} 4_{3}^{2}
\end{array}\right\} \\
& =\left\{\begin{array}{l}
15,23^{2}+14,21^{2}+14,55^{2}+14,89^{2}+15,73^{2}+15,57^{2} \\
+15,90^{2}+16,41^{2}+13,532+13,53^{2}+12,86^{2}+ \\
13.87^{2}-\mathrm{FK}
\end{array}\right\}
\end{aligned}
$$$$
=3.464,68-3.447,08
$$$$
=17,28
$$

$\mathrm{Jk}$ perlakuan

$$
\begin{aligned}
& =\left(\begin{array}{l}
\left(\sum_{\mathrm{j}-\mathrm{i}}^{5} \mathrm{Y} 1_{\mathrm{j}}^{2}+\sum_{\mathrm{j}-\mathrm{i}}^{5} \mathrm{Y} 2_{\mathrm{j}}^{2}+\sum_{\mathrm{j}-\mathrm{i}}^{5} \mathrm{Y} 3_{\mathrm{j}}{ }^{2}+\sum_{\mathrm{j}-\mathrm{i}}^{5} \mathrm{Y}-\mathrm{FK} 4_{\mathrm{j}}^{2}+\sum_{\mathrm{j}-\mathrm{i}}^{5} \mathrm{Y} 5_{\mathrm{j}}^{2}\right)
\end{array}\right) \\
& =\left[\begin{array}{l}
(43,99)^{2}+(46,19)^{2}+(48,22)^{2}+(48,73)^{2}+ \\
(40,27)^{2 / 3}-3.447,08
\end{array}\right] \\
& =16,28
\end{aligned}
$$

$\mathrm{Jk}_{\mathrm{G} . P e r c o b a a n}$

$=J K_{\text {Total }}-J K_{\text {Perlakuan }}$

$=17,28-16,28$

$$
=1
$$

4) Menghitung KT setiap sumber keragaman

$$
\begin{aligned}
& \mathrm{KT}_{\text {perlakuan }} \\
& \quad=\mathrm{JK}_{\text {perlakuan }} / \mathrm{DB}_{\text {Perlakuan }} \\
& =16,28 / 4 \\
& \quad=4,07
\end{aligned}
$$

$\mathrm{KT}_{\text {percobaan }}$

$$
\begin{aligned}
& =\mathrm{JK}_{\mathrm{G} \cdot \text { percobaan }} / \mathrm{DB}_{\text {Percobaan }} \\
& =1 / 10 \\
& =0,1
\end{aligned}
$$

5) Menghitung $F_{\text {hitung }}$

$$
\begin{aligned}
\mathrm{F}_{\text {hitung }} & =\mathrm{KT}_{\text {perlakuan }} / \mathrm{KT}_{\text {G.percobaan }} \\
& =4,07 / 0,1 \\
& =40,7
\end{aligned}
$$

6) Menyusun tabel analisis ragam gula Value plus dapat dilihat pada tabel 10 :

Tabel 10. Hasil uji F gula Value plus

\begin{tabular}{|c|c|c|c|c|}
\hline Sk & DB & JK & KT & $F_{\text {hitung }}$ \\
\hline Perlakuan & 4 & 17,28 & 3,54 & 40,7 \\
\hline J.Percobaan & 10 & 16,28 & 0,14 & - \\
\hline Total & 13 & 33,56 & $3,415,90^{2}$ & $40,5.24^{2}$ \\
\hline
\end{tabular}

(Sumber : Penelitian, 2018)

Dari tabel persentase distribusi $F_{\text {tabel }}$ dapat dilihat bahwa $\mathrm{F}_{\text {Tabel }}$ untuk $\mathrm{F}_{0,05}=3,48$ untuk $\mathrm{F}_{0,01}=$ 6,55 sedangkan $F_{\text {hitung }}=40.7$ karena $F_{\text {hitung }}>F_{\text {tabel }}$ maka dapat disimpulkan bahwa terdapat interaksi atau perlakuan yang sangat nyata antara kuat.

b. Analisis statistik pada gula merek Berlian jaya. Analisis statistik pada gula merek Berlian jaya dapat dilihat pada tabel 11 .

Tabel 11. Analisis statistik pada gula Berlian jaya

\begin{tabular}{|l|c|c|c|c|c|}
\hline \multirow{2}{*}{ No } & $\begin{array}{c}\text { Variasi } \\
\text { campura } \\
\text { n gula } \\
\text { pasir (\%) }\end{array}$ & \multicolumn{2}{|c|}{ Kuat Tekan Benda Uji (MPa) } & \multirow{2}{*}{ Total } \\
\cline { 3 - 5 } & 11 & $\begin{array}{c}\text { Sampe } \\
12\end{array}$ & $\begin{array}{c}\text { Sampe } \\
13\end{array}$ & \\
\hline 1 & $0 \%$ & 15,23 & 14,21 & 14,55 & $\sum_{j-1}^{5} Y_{2 j}=43,99$ \\
\hline 2 & $0,05 \%$ & 15,06 & 15,23 & 15,23 & $\sum_{\mathrm{j}-1}^{5} \mathrm{Y}_{2 \mathrm{j}}=45,51$ \\
\hline 3 & $0,10 \%$ & 15,57 & 15,90 & 15,73 & $\sum_{\mathrm{j}-1}^{5} \mathrm{Y}_{3 \mathrm{j}}=47,20$ \\
\hline
\end{tabular}




\begin{tabular}{|c|c|c|c|c|c|}
4 & $0,15 \%$ & 15,90 & 15,57 & 15,23 & $\sum_{j-1}^{5} \mathrm{Y}_{4 \mathrm{j}}=46,70$ \\
\hline 5 & $0,20 \%$ & 13,87 & 12,86 & 13.20 & $\sum_{\mathrm{j}-1}^{5} \mathrm{Y}_{5 \mathrm{j}}=46,70$ \\
\hline \multicolumn{4}{|c|}{ Total } & $\sum_{i=1}^{4} \sum_{j=1}^{5} Y_{j}$ \\
$=223,39$
\end{tabular}

(Sumber : Hasil penelitian,2018)

1) Menentukan derajat bebas

$$
\begin{aligned}
\text { Db Perlakuan } & =(\mathrm{p}-1) \\
& =(5-1)=4 \\
\text { Db Percobaan } & =\mathrm{p}(\mathrm{n}-1) \\
& =5(3-1)=10
\end{aligned}
$$

2) Menghitung faktor koreksi

$$
\begin{aligned}
& \text { FK }\left(\sum_{i=1}^{p}=\sum_{j=1}^{n} Y_{i j} / p . n\right. \\
& =(227,39)^{2} /(5 \times 3) \\
& =3.447,08
\end{aligned}
$$

3) Menghitung jumlah-jumlah kuadrat yang Diperlukan.

Jk total $=\left(Y 1 j^{2}+Y 2 j^{2}+Y 3 j^{2}\right)-F K$

$$
\begin{aligned}
& \left\{\begin{array}{l}
\mathrm{Y} 1_{1}^{2}+\mathrm{Y} 1_{2}^{2}+\mathrm{Y} 1_{3}^{2}+\mathrm{Y} 2_{1}^{2}+\mathrm{Y} 2_{2}^{2}+\mathrm{Y} 2_{3}^{2}+ \\
\mathrm{Y} 3_{1}^{2}+\mathrm{Y} 3_{2}^{2}+\mathrm{Y} 3_{3}^{2}+\mathrm{Y} 4_{1}^{2}+\mathrm{Y} 4_{2}^{2}+\mathrm{Y} 4_{3}^{2}+ \\
\mathrm{Y} 5_{1}^{2}+\mathrm{Y} 5_{2}^{2}+\mathrm{Y} 5_{3}^{2}-\mathrm{FK}
\end{array}\right\} \\
& =\left\{\begin{array}{l}
15,23^{2}+14,21^{2}+14,55^{2}+15,06^{2}+15,23^{2} \\
+15,23^{2}+15,57^{2}+15.90^{2}+15,73^{2}+ \\
15,90^{2}+15,57+15,23^{2}+13,87^{2}+12,86^{2} \\
13,20^{2}-\mathrm{FK}
\end{array}\right\}
\end{aligned}
$$$$
=3,337,76-3.325,08
$$$$
=12,68
$$

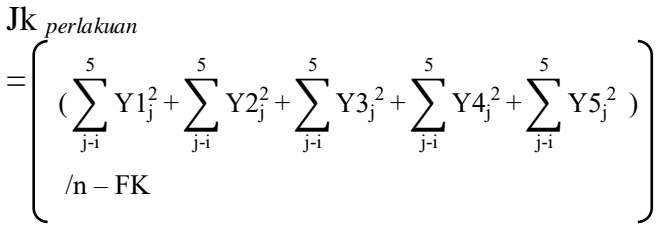

$$
\begin{aligned}
& =\left[\begin{array}{l}
(43,99)^{2}+(45,51)^{2}+(47,20)^{2}+(46,70)^{2}+ \\
(39,93)^{2} / 3-3.325,71
\end{array}\right] \\
& =10,63 \\
& \mathrm{Jk}_{\mathrm{G} . P e r c o b a a n} \\
& =J K_{\text {Total }}-J K_{\text {Perlakuan }} \\
& =12,05-10,63 \\
& =1,42
\end{aligned}
$$

4) Menghitung KT setiap sumber keragaman

$$
\begin{aligned}
\mathrm{KT}_{\text {perlakuan }} & =\mathrm{JK}_{\text {perlakuan }} / \mathrm{DB}_{\text {Perlakuan }} \\
& =10,63 / 4
\end{aligned}
$$

$$
\begin{aligned}
& =2,65 \\
\mathrm{KT}_{\text {percobaan }} & =\mathrm{JK}_{\text {G.percobaan }} / \mathrm{DB}_{\text {Percobaan }} \\
& =1,42 / 10 \\
& =0,14
\end{aligned}
$$

\begin{tabular}{|c|c|c|c|c|c|}
\hline \multirow[b]{2}{*}{ No } & \multirow{2}{*}{$\begin{array}{c}\text { Variasi } \\
\text { campuran } \\
\text { gula pasir } \\
(\%)\end{array}$} & \multicolumn{3}{|c|}{ Kuat Tekan Benda Uji (MPa) } & \multirow[b]{2}{*}{ Total } \\
\hline & & $\underset{1}{\text { Sampel }}$ & $\begin{array}{c}\text { Sampel } \\
2\end{array}$ & Sampel 3 & \\
\hline 1 & $0 \%$ & 15,23 & 14,21 & 14,55 & $\begin{array}{l}\sum_{j=1}^{5} Y_{2 j} \\
=43,99\end{array}$ \\
\hline 2 & $0,05 \%$ & 15,06 & 15,57 & 15,23 & $\begin{array}{l}\sum_{j=1}^{5} Y_{2 j} \\
=45,85\end{array}$ \\
\hline 3 & $0,10 \%$ & 15,23 & 15,23 & 15,57 & $\begin{array}{l}\sum_{j=1}^{5} Y_{3 j} \\
=46,02\end{array}$ \\
\hline 4 & $0,15 \%$ & 15,90 & 16,24 & 16,92 & $\begin{array}{l}\sum_{j=1}^{5} Y_{4 j} \\
=49,06\end{array}$ \\
\hline 5 & $0,20 \%$ & 13,87 & 12,87 & 12.86 & $\begin{array}{l}\sum_{j=1}^{5} Y_{5 j} \\
=40,60\end{array}$ \\
\hline & & Total & & & $\sum_{i=1}^{4} \sum_{j=1}^{5} Y i_{j}$ \\
\hline
\end{tabular}

5) Menghitung F

$$
\begin{aligned}
\mathrm{F}_{\text {hitung }} & =\mathrm{KT}_{\text {perlakuan }} / \mathrm{KT}_{\mathrm{G} \text {.percobaan }} \\
& =3,54 / 0,14 \\
& =25,28
\end{aligned}
$$

6) Menyusun tabel analisis ragam gula Berlian jaya dapat dilihat pada tabel 12 :

Tabel 12. Hasil uji F gula Berlian Jaya

\begin{tabular}{|c|c|c|c|c|}
\hline Sk & DB & JK & KT & $F_{\text {hitung }}$ \\
\hline Perlakuan & 4 & 10,63 & 2,65 & 25,28 \\
\hline G. Percobaan & 10 & 10,63 & 0,14 & - \\
\hline Total & 14 & 22,68 & 3,68 & 25,28 \\
\hline
\end{tabular}

(Sumber : Hasil penelitian, 2018)

Dari tabel persentase distribusi $\mathrm{F}_{\text {tabel }}$ dapat dilihat bahwa $\mathrm{F}_{\text {Tabel }}$ untuk $\mathrm{F}_{0,05}=3,71$ untuk $\mathrm{F}_{0,01}=6,55$ sedangkan $\mathrm{F}_{\text {hitung }}=25,28$ karena $\mathrm{F}_{\text {hitung }}>\mathrm{F}_{\text {tabel }}$ maka dapat disimpulkan bahwa terdapat interaksi atau perlakuan yang sangat nyata antara kuat tekan mortar terhadap variasi campuran gula pasir.

c. Analisis stastik pada merek gulaku

Analisis statistik pada gula merek Gulaku dapat dilihat pada tabel 13:

Tabel 13. Analisis stastik pada merek gulaku. 
(Sumber : Hasil penelitian,2018)

1) Menentukan derajat bebas

$$
\begin{aligned}
\mathrm{Db}_{\text {Perlakuan }} & =(\mathrm{p}-1) \\
& =(5-1)=4 \\
\mathrm{Db} & \\
\text { Percobaan } & =\mathrm{p}(\mathrm{n}-1) \\
& =5(3-1)=10
\end{aligned}
$$

2) Menghitung faktor koreksi

$$
\begin{aligned}
\text { FK } & =\left(\sum_{i=1}^{p} \sum_{j=1}^{n} Y_{i j} / p . n\right. \\
& =(225,53)^{2} /(5 \times 3) \\
& =3.390,91
\end{aligned}
$$

3) Menghitung jumlah-jumlah kuadrat yang diperlukan

Jk total $=\left(Y 1 j^{2}+Y 2 j^{2}+Y 3 j^{2}\right)-F K$

$$
\begin{aligned}
& \left\{\begin{array}{l}
\mathrm{Y} 1_{1}{ }^{2}+\mathrm{Y} 1_{2}{ }^{2}+\mathrm{Y} 1_{3}{ }^{2}+\mathrm{Y} 2_{1}{ }^{2}+\mathrm{Y} 2_{2}{ }^{2}+\mathrm{Y} 2_{3}{ }^{2}+ \\
\mathrm{Y} 3_{1}{ }^{2}+\mathrm{Y} 3_{2}{ }^{2}+\mathrm{Y} 5_{2}{ }^{2}+\mathrm{Y} 3_{3}{ }^{2}+\mathrm{Y} 4_{1}{ }^{2}+\mathrm{FK}
\end{array}\right\} \\
& =\left\{\begin{array}{l}
15,23_{2}^{2}+\mathrm{Y} 4_{3}{ }^{2}+ \\
+14,21^{2}+14,55^{2}+15,06^{2}+15,57^{2} \\
13,87^{2}+13,87^{2}+15.23^{2}+15,57^{2}+
\end{array}\right\} \\
& =3.405,63-3.290,91 \\
& =14,72
\end{aligned}
$$

$$
\begin{aligned}
& \mathrm{Jk}_{\text {perlakuan }} \\
& \left.=\left(\sum_{\substack{\mathrm{j}-\mathrm{i} \\
/ \mathrm{n}-\mathrm{FK}}}^{5} \mathrm{Y} 1_{\mathrm{j}}^{2}+\sum_{\mathrm{j}-\mathrm{i}}^{5} \mathrm{Y} 2_{\mathrm{j}}{ }^{2}+\sum_{\mathrm{j}-\mathrm{i}}^{5} \mathrm{Y} 3_{\mathrm{j}}{ }^{2}+\sum_{\mathrm{j}-\mathrm{i}}^{5} \mathrm{Y} 4_{\mathrm{j}}{ }^{2}+\sum_{\mathrm{j}-\mathrm{i}}^{5} \mathrm{Y} 5_{\mathrm{j}}{ }^{2}\right)\right) \\
& =\left[\begin{array}{l}
(43,99)^{2}+(46,85)^{2}+(46,02)^{2}+(49,06)^{2}+ \\
(40,60)^{2} / 3-3.90,91
\end{array}\right]
\end{aligned}
$$$$
=12,75
$$

$\mathrm{Jk}_{\mathrm{G} . P e r c o b a a n}$

$$
\begin{aligned}
& =J K_{\text {Total }}-J K_{\text {Perlakuan }} \\
& =14,72-12,75=1,97
\end{aligned}
$$

4) Menghitung KT setiap sumber keragaman

$$
\begin{aligned}
& \mathrm{KT}_{\text {perlakuan }} \\
& =\mathrm{JK}_{\text {perlakuan }} / \mathrm{DB}_{\text {Perlakuan }} \\
& =12,75 / 4 \\
& =3,18 \\
& \mathrm{KT}_{\text {percobaan }} \\
& =\mathrm{JK}_{\text {G.percobaan }} / \mathrm{DB}_{\text {Percobaan }}
\end{aligned}
$$

\begin{tabular}{|c|c|c|c|c|c|}
\hline \multirow[b]{2}{*}{ No } & \multirow{2}{*}{$\begin{array}{c}\text { Variasi } \\
\text { campuran } \\
\text { gula pasir } \\
(\%)\end{array}$} & \multicolumn{3}{|c|}{ Kuat Tekan Benda Uji (MPa) } & \multirow[b]{2}{*}{ Total } \\
\hline & & $\begin{array}{c}\text { Sampel } \\
1\end{array}$ & $\begin{array}{c}\text { Sampel } \\
2\end{array}$ & $\begin{array}{c}\text { Sampel } \\
3\end{array}$ & \\
\hline 1 & $0 \%$ & 15,23 & 14,21 & 14,55 & $\begin{array}{l}\sum_{j-1}^{5} Y_{2 j} \\
=43,99\end{array}$ \\
\hline 2 & $0,05 \%$ & 15,57 & 15,06 & 15,23 & $\begin{array}{l}\sum_{j-1} Y_{2 j} \\
=45,85\end{array}$ \\
\hline 3 & $0,10 \%$ & 15,57 & 15,06 & 15,73 & $\begin{array}{l}\sum_{j-1} Y_{3 j} \\
=46,36\end{array}$ \\
\hline 4 & $0,15 \%$ & 16,07 & 16,07 & 16,58 & $\begin{array}{l}\sum_{j-1}^{5} Y_{4 j} \\
=48,73\end{array}$ \\
\hline 5 & $0,20 \%$ & 12,86 & 14,21 & 12.52 & $\begin{array}{l}\sum_{j-1}^{5} Y_{5 j} \\
=39,59\end{array}$ \\
\hline
\end{tabular}

$$
\begin{aligned}
& =1,97 / 10 \\
& =0,19
\end{aligned}
$$

5) Menghitung $F_{\text {hitung }}$

$$
\begin{aligned}
\mathrm{F}_{\text {hitung }} & =\mathrm{KT}_{\text {perlakuan }} / \mathrm{KT}_{\mathrm{G} . \text { percobaan }} \\
& =3,18 / 0,19 \\
& =16,73
\end{aligned}
$$

6) Menyusun tabel analisis ragam gula Gulaku dapat dilihat pada tabel 14

Tabel 14. Hasil uji F gula Gulaku

\begin{tabular}{|c|c|c|c|c|}
\hline Sk & DB & JK & KT & $F_{\text {hitung }}$ \\
\hline Perlakuan & 4 & 14,72 & 3,18 & 16,37 \\
\hline $\begin{array}{c}\text { G. } \\
\text { Percobaan }\end{array}$ & 10 & 12,75 & 0,19 & - \\
\hline Total & 14 & 27,47 & 3,37 & 16,37 \\
\hline
\end{tabular}

(Sumber : Hasil penelitian,2018)

Dari tabel persentase distribusi $F_{\text {tabel }}$ dapat dilihat bahwa $\mathrm{F}_{\text {Tabel }}$ untuk $\mathrm{F}_{0,05}=3,48$ untuk $\mathrm{F}_{0,01}=6,55$ sedangkan $\mathrm{F}_{\text {hitung }}=16,37$ karena $F_{\text {hitung }}>F_{\text {tabel }}$ maka dapat disimpulkan bahwa terdapat interaksi atau perlakuan yang sangat nyata antara kuat tekan mortar terhadap variasi campuran gula pasir merek Gulaku.

d. Analisis statistik untuk gula merek gula Lokal Analisis stastik pada merek gula Lokal dapat dilihat pada tabel 15 .

Tabel 15. Tabel rancangan perlakuan pada gula merek Lokal. 


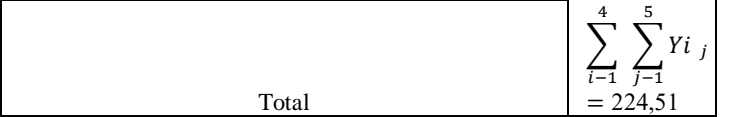

(Sumber : Hasil penelitian,2018)

1) Menentukan derajat bebas

$$
\begin{aligned}
\text { Db Perlakuan } & =(\mathrm{p}-1) \\
& =(5-1)=4 \\
\text { Db Percobaan } & =\mathrm{p}(\mathrm{n}-1) \\
& =5(3-1)=10
\end{aligned}
$$

2) Menghitung faktor koreksi

$$
\begin{aligned}
\mathrm{FK} & =\left(\sum_{\mathrm{i}=1}^{\mathrm{p}} \sum_{\mathrm{j}=1}^{\mathrm{n}} \mathrm{Y}_{\mathrm{ij}} / \mathrm{p} . \mathrm{n}\right. \\
& =(224,51)^{2} /(5 \times 3) \\
& =3.360,31
\end{aligned}
$$

3) Menghitung jumlah-jumlah kuadrat yang diperlukan

Jk total

$$
\begin{aligned}
& =\left(Y 1 j^{2}+Y 2 j^{2}+Y 3 j^{2}\right)-F K \\
& \left\{\begin{array}{l}
\mathrm{Y} 1_{1}{ }^{2}+\mathrm{Y} 1_{2}{ }^{2}+\mathrm{Y} 1_{3}{ }^{2}+\mathrm{Y} 2_{1}{ }^{2}+\mathrm{Y} 2_{2}{ }^{2}+\mathrm{Y} 2_{3}{ }^{2}+ \\
\mathrm{Y} 3_{1}{ }^{2}+\mathrm{Y} 3_{2}^{2}+\mathrm{Y} 3_{3}{ }^{2}+\mathrm{Y} 4_{1}^{2}+\mathrm{Y} 4_{2}^{2}+\mathrm{Y} 4_{3}{ }^{2}+ \\
\mathrm{Y} 5_{1}{ }^{2}+\mathrm{Y} 5_{2}^{2}+\mathrm{Y} 5_{3}{ }^{2}-\mathrm{FK}
\end{array}\right\} \\
& =\left\{\begin{array}{l}
15,23^{2}+14,21^{2}+14,55^{2}+15,06^{2}+15,57^{2} \\
+15,06^{2}+15,73^{2}+16.07^{2}+16,58^{2}+12,86^{2} \\
+14,21^{2}+12,57^{2}-\mathrm{FK}
\end{array}\right\} \\
& =3.378,61-3.360,31 \\
& =18,30 \\
& \mathrm{Jk}_{\text {perlakuan }}
\end{aligned}
$$

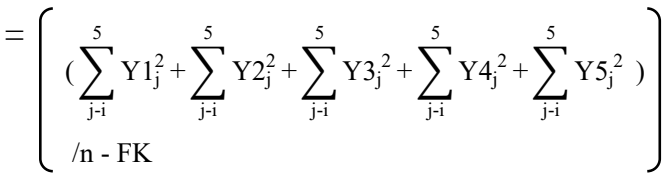

$$
\begin{aligned}
& =\left[\begin{array}{c}
(43,99)^{2}+(45,85)^{2}+(46,36)^{2} \\
+(48,73)^{2}+(39,59)^{2}-3.360,31
\end{array}\right] \\
& =15,61 \\
& \mathrm{Jk}_{\mathrm{G} . \text { Percobaan }}=J K_{\text {Total }}-J K_{\text {Perlakuan }} \\
& =18,30-15,60 \\
& =2,69
\end{aligned}
$$

4) Menghitung KT setiap sumber keragaman

$$
\begin{aligned}
\mathrm{KT}_{\text {perlakuan }} & =\mathrm{JK}_{\text {perlakuan }} / \mathrm{DB}_{\text {Perlakuan }} \\
& =15,61 / 4 \\
& =2,69 \\
\mathrm{KT}_{\text {percobaan }} & =\mathrm{JK}_{\text {G.percobaan }} / \mathrm{DB}_{\text {Percobaan }} \\
& =2,69 / 4 \\
& =0,26
\end{aligned}
$$

5) Menghitung F Fitung

$$
\begin{aligned}
\mathrm{F}_{\text {hitung }} & =\mathrm{KT}_{\text {perlakuan }} / \mathrm{KT}_{\mathrm{G} \text {.percobaan }} \\
& =3,90 / 0,26 \\
& =15
\end{aligned}
$$

6) Menyusun tabel analisis ragam gula Lokal dapat dilihat pada tabel 16 :

Tabel 16. Hasil uji F gula Lokal

\begin{tabular}{|c|c|c|c|c|}
\hline Sk & DB & JK & KT & $F_{\text {hitung }}$ \\
\hline Perlakuan & 4 & 18,30 & 3,90 & 15 \\
\hline $\begin{array}{c}\text { G. } \\
\text { Percobaan }\end{array}$ & 10 & 15,61 & 0,26 & - \\
\hline Total & 14 & 33,91 & 4,16 & 15 \\
\hline
\end{tabular}

(Sumber : Hasil penelitian,2018)

Dari tabel persentase distribusi $\mathrm{F}_{\text {tabel }}$ dapat dilihat bahwa $\mathrm{F}_{\text {Tabel }}$ untuk $\mathrm{F}_{0,05}=3,48$ untuk $\mathrm{F}_{0,01}=6,55$ sedangkan $\mathrm{F}_{\text {hitung }}=15$ karena $\mathrm{F}_{\text {hitung }}>\mathrm{F}_{\text {tabel }}$ maka dapat disimpulkan bahwa terdapat interaksi atau perlakuan yang sangat nyata antara kuat tekan mortar terhadap variasi campuran gula pasir merek gula lokal

\section{Pembahasan}

Dari hasil yang diperoleh pada penelitian yang dilakukan dilaboratorium PT. Riau Mas Bersaudara dapat diketahui kuat tekan mortar semen terhadap variasi campuran gula pasir dengan pencampuran $0 \%$, $0,05 \%, 0,1 \%, 0,15 \%, 0,2 \%$ menggunakan gula merek Value plus, Berlian jaya, Gulaku, dan gula lokal, dengan Fas 0,5 dan perbandingan semen : pasir (1:5) diperoleh kenaikan kuat tekan tertinggi pada gula merek gulaku dengan pencampuran $0,15 \%$ dengan nilai kuat tekan sebesar 16, $35 \mathrm{MPa}$ namun kuat tekan kembali turun pada pencampuran $0,2 \%$ yaitu sebesar 13,53 MPa. Tren kenaikan dan penurunan yang sama juga dialami pada campuran merek gula lainya.

Untuk mengetahui pengaruh campuran gula pasir dari setiap campuran merek gula dapat dilihat pada tabel 12.

Tabel 12. Rekapitulasi hasil analisis statistik pengaruh kuat tekan mortar semen terhadap variasi campuran gula pasir.

\begin{tabular}{|c|c|c|c|c|}
\hline \multirow{2}{*}{ No } & \multirow{2}{*}{ Merek Gula } & \multicolumn{2}{|c|}{$\mathrm{F}_{\text {tabel }}$} & \multirow{2}{*}{$\mathrm{F}_{\text {hitung }}$} \\
\cline { 3 - 4 } & & $\mathrm{F}_{0,01}$ & $\mathrm{~F}_{0,05}$ & \\
\hline 1 & Value Plus & 6,55 & 3,48 & 40,7 \\
\hline 2 & Berlian Jaya & 6,55 & 3,48 & 25,28 \\
\hline 3 & Gulaku & 6,55 & 3,48 & 16,37 \\
\hline 4 & Gula Lokal & 6,55 & 3,48 & 15,00 \\
\hline
\end{tabular}

(Sumber : Hasil penelitian,2018)

Dari rekapitulasi hasil analisis statistik pada tabel 4.12 dapat dilihat bahwa gula merek Value plus $\mathrm{F}_{\text {tabel }}$ untuk $\mathrm{F}_{0,05}=3,48$ untuk $\mathrm{F}_{0,01}=6,55$ sedangkan 
f hitung $=40,7$ karena $F_{\text {hitung }}>F_{\text {tabel }}$ maka dapat disimpulkan bahwa terdapat interaksi atau pengaruh yang sangat nyata antara variasi campuran gula merek Value plus terhadap kuat tekan mortar semen. Gula merek Berlian jaya $F_{\text {tabel }}$ untuk $F_{0,05}=3,48$ untuk $F_{0,01}$ $=6,55$ sedangkan $F_{\text {hitung }}=25,58$ karena $F_{\text {hitung }}>F_{\text {tabel }}$ maka dapat disimpulkan bahwa terdapat interaksi atau pengaruh yang sangat nyata antara variasi campuran gula merek Belian jaya terhadap kuat tekan mortar semen. Gula merek gulaku $\mathrm{F}_{\text {tabel }}$ untuk $\mathrm{F}_{0,05}=3,48$ untuk $F_{0,01}=6,55$ sedangkan $F_{\text {hitung }}=16,37$ karena $\mathrm{F}_{\text {hitung }}>\mathrm{F}_{\text {tabel }}$ maka dapat disimpulkan bahwa terdapat interaksi atau pengaruh yang sangat nyata antara variasi campuran gula merek Gulaku terhadap kuat tekan mortar semen. Gula merek Lokal $\mathrm{F}_{\text {tabel }}$ untuk $\mathrm{F}_{0,05}=3,48$ untuk $\mathrm{F}_{0,01}=6,55$ sedangkan $\mathrm{F}_{\text {hitung }}=15$ karena $F_{\text {hitung }}>F_{\text {tabel }}$ maka dapat disimpulkan bahwa terdapat interaksi atau pengaruh yang sangat nyata antara variasi campuran gula pasir merek Lokal terhadap kuat tekan mortar semen.

Untuk hasil pengujian kuat tekan yang dilakukan didapat nilai kuat tekan yang terus meningkat seiring dengan penambahan campuran gula pasir yaitu dengan penambahan $0,15 \%$ yaitu sebesar $16,35 \mathrm{MPa}$ pada campuran gula merek gulaku, namun kuat tekan kembali turun dengan penambahan gula sebesar $0,2 \%$ sebesar 13,20 MPa nilai kuat tekan terendah pada gula merek gula lokal. Trend kenaikan dan penurunan juga terjadi pada gula merek lainya.

\section{KESIMPULAN DAN SARAN}

\section{Kesimpulan}

Berdasarkan hasil penelitian yang dilakukan diperoleh hasil :

1. $F_{\text {Hitung }}$ untuk gula Merek Value plus $=40,7$, untuk gula merek berlian jaya $\mathrm{F}_{\text {hutung }}=25,28$, merek Gulaku $F_{\text {hitung }}=16,37$, dan gula merek Lokal $F_{\text {hitung }}=15$. Sedangkan $F_{\text {tabel }}$ untuk $F_{0,05}=3,48$ dan $\mathrm{F}_{0,01}=6,55$.

2. Karena $\mathrm{F}_{\text {hitung }}>\mathrm{F}_{\text {tabel }}$ maka disimpulkan bahwa terdapat interaksi atau pengaruh yang sangat nyata antara variasi campuran gula pasir terhadap kuat tekan mortar semen .

3. Untuk hasil uji kuat tekan yang didapat, nilai kuat tekan yang tertinggi yaitu pada merek gulaku sebesar 16,35 dengan campuran $0,15 \%$. nilai kuat tekan terendah pada gula merek gula lokal Sebesar $13,20 \mathrm{MPa}$ dengan campuran $0,2 \%$

4. Nilai kuat tekan terus naik hingga pencampuran $0,15 \%$ dan kembali turun pada campuran $0,2 \%$, tren kenaikan dan penurunan yang sama terjadi pada seluruh merek gula.

\section{Saran}

1. Untuk lebih mengetahui sifat dan karakteristik mortar semen dengan campuran gula pasir sebaiknya dilakukan dengan umur perawatan benda uji lebih bervariasi

2. Penggunaan mortar semen untuk pekerjaan konstruksi lebih ditingkatkan lagi kualitasnya salah satunya dengan menggunakan campuran gula pasir.

3. Untuk penelitian selanjutnya sebaiknya menggunakan benda uji beton.

\section{DAFTAR PUSTAKA}

Antoni dan Nugraha P. 2007. Teknologi Beton. Yogyakarta : C.V Andi Offset.

ASTM C270-10-2010. Standard Spesification For Mortar For Unit Masonry. Pennsilvania : American Society For Testing And Material.

Badan Standarisasi Nasional. 2004. Semen Portland SNI 03-2847-2004. Jakarta : BSN.

Badan Standarisasi Nasional. 2002. Metode Pengujian Kekuatan Tekan Mortar Semen Portland Untuk Pekerjaan Sipil SNI 03- 6825-2002. Jakarta : BSN.

Badan Standarisasi Nasional. 2004. Spesifikasi Mortar Untuk Pekerjaan Pasangan SNI 153758-2004. Jakarta : BSN.

Departemen Pekerjaan Umum. 1989. Pedoman Beton SKBI.1-4-53-1989. Jakarta : Departemen PU

Febriningsih S. 2015. Analisis Perbandingan Waktu Ikat Awal Semen Dengan Variasi Penambahan Gula (Skripsi). Pekanbaru : Program Studi Teknik Sipil, Universitas Lancang Kuning.

Mulyono T. 2004. Teknologi Beton. Yogyakarta : C.V Andi Offset.

Neville AM. 1995. Properties of Concrete (Fifth Edition). London : Longman Group Limited.

Puryanto dkk. 2014. Pengaruh Penambahan Gula Pasir Terhadap Setting Time Semen dan Kuat Tekan Mortar Yang Menggunakan Pasir Lokal. Jurnal Teknik Sipil. Volume 10. Nomor 2. September $2014: 115$ - 123 .

Rifany DK dkk. 2008. Penggunaan Gula Pasir Lokal Sebagai Plasticizer Pada Adukan Mortar Untuk Pembuatan Conblock. Jurnal Teknik Sipil. Volume 18 Nomor 3. September 2008 : 869 878.

Tjokrodimuljo K. 1996. Teknologi Beton. Yogyakarta. : Jurusan Teknik Sipil Fakultas Teknik UGM. Yitnosumarto S. 1991. Dasar - Dasar Statistika. Jakarta : Penerbit Rajawali Pers. 